\title{
VOLTAMMETRIC BEHAVIOR AND DETERMINATION OF THE BRONCHODILATOR DOXOFYLLINE AT A BORONDOPED DIAMOND ELECTRODE
}

\author{
Sachin Saxena*, Ratnanjali Shrivastava, Soami P. Satsangee \\ USIC, Dayalbagh Educational Institute, Dayalbagh, Agra-282110, India
}

sachinusic@gmail.com

\begin{abstract}
The electrochemical behavior of the asthma drug doxofylline was studied at a boron-doped diamond electrode in BR buffer ( $\mathrm{pH}$ 3.8) by square-wave voltammetry. Cyclic voltammetry revealed the oxidation of doxofylline as an irreversible diffusion-controlled process. The oxidation mechanism was proposed and the drug was studied in the presence of solubilized systems like Tween-20 (T-20), sodium dodecyl sulfate (SDS), Triton X-100 (TTN), dioxane (DO), dimethylformamide (DMF), diethyl ether (DEE), benzene and methanol $(\mathrm{MeOH})$. Comparison of the current responses in the solution system explained the sensitivity of the boron-doped diamond electrode (BDDE) with a three-fold increase in the current value compared to that of a glassy carbon electrode (GCE) at a fixed concentration of doxofylline. Peak current values varied linearly with increasing concentration and the LOD and LOQ were found to be 3.48 and $10.56 \mu \mathrm{g} / \mathrm{ml}$, respectively. This method was employed to investigate doxofylline in the pharmaceutical formulation.
\end{abstract}

Key words: doxofylline; BDDE; voltammetry; pharmaceutical formulation

\section{ВОЛТАМЕТРИСКО ОДНЕСУВАЊЕ И ОПРЕДЕЛУВАЊЕ НА БРОНХОДИЛАТАТОРОТ ДОКСОФИЛИН СО ДИЈАМАНТСКА ЕЛЕКТРОДА КОЈА СОДРЖИ БОР}

\footnotetext{
Електрохемиското однесување на лекот доксофилин, кој се користи како супресор за астма, е испитувано со квадратнобранова волтаметрија во Britton-Robinson-ов пуфер со рН 3,8 со употреба на дијамантска електрода што содржи бор. Со помош на циклична волтаметрија е утврдено дека оксидацјата на доксофилин е иреверзибилен и дифузиски контролиран редокс-процес. Лекот доксофилин е ипситуван во присуство на triton X-100 (TTN), диоксан (DO), диметилформамид $(\mathrm{DMF})$, диетил етер (DEE), бензен и метанол (MeOH), при што е утврден механизмот на неговата оксидација. Со споредбата на електрохемискиот одговор на дијамантската електрода во однос на стаклена јаглеродна електрода е покажано дека струјата на дијамантската електрода што содржи бор (BDDE) е три пати поголема во споредба со струјата измерена на стаклената јаглеродна електрода (GCE) при константна концентрација на доксофилин. Утврдено е дека вредноста на пикот на струјата се менува линеарно со зголемување на концентрацијата на доксофилин, при што границата на детекција (LOD) и границата на квантификација (LOQ) изнесуват 3,48 и 10,56 $\mu \mathrm{g} / \mathrm{ml}$, соодветно. Методот е применет за испитување на доксофилин во фармацевтски препарати.
}

Клучни зборови: доксофилин; BDDE; волтаметрија; фармацевтски препарат 


\section{INTRODUCTION}

The development of simple and accurate methods for detecting the active ingredients of drugs is important because drug monitoring plays an important role in drug quality control [1]. Doxofylline (7-(1,3-dioxolan2-ylmethyl)-1,3-dimethylpurine-2,6-dione) is a bronchodilator xanthine drug with good therapeutic properties a low incidence of side effects $[2,3]$. It plays a direct role in mediating the relaxation of bronchial smooth muscle cells, thereby enhancing smooth muscle relaxation and suppressing the symptoms of asthma. It acts as a phosphodiesterase inhibitor and is well-tolerated by the cardiovascular, digestive and central nervous systems [4].<smiles>Cn1c(=O)c2c(ncn2CC2OCCO2)n(C)c1=O</smiles>

Different analytical methods have been developed to quantify doxofylline in bulk and pharmaceutical preparations. The most commonly employed techniques are HPLC [5-8], spectrophotometry [9], HPTLC [10], HPLC chromatography [11] and LC-MS/MS [12]. However, these methods involve several manipulation steps which are time-consuming, use significant amounts of solvents and require sophisticated instrumentation. On the other hand, electrochemical techniques are highly sensitive, inexpensive, less time-consuming and provide a quick response; hence, these methods can be considered a strong alternative to the abovementioned methods [13-18]. An extensive literature survey revealed that the electrochemical method has so far not been reported for studies on doxofylline.

Moreover, for trace determination of redox systems, the good chemical and electrochemical stability of doped diamond electrodes has been considered one of the major advan- tages as compared to conventional electrode materials [19-20]. Boron doping is by far the most widely used dopant to produce conducting diamond electrodes. This is because boron has a low charge carrier activation energy of $0.37 \mathrm{eV}[21]$. Boron doping leads to a p-type semiconductor [22]. Therefore, boron-doped diamond electrodes (BDDE) can be used effectively in electrochemical estimations.

The present communication reports an electrochemical method for the study of doxofylline in its pharmaceutical formulation using square-wave voltammetry (SWV) and cyclic voltammetry (CV). A BDDE was employed for the effective determination of doxofylline and the results indicate improved electrochemical detection of doxofylline compared to detection with a glassy carbon electrode.

\section{EXPERIMENTAL}

\subsection{Apparatus}

Electrochemical measurements were carried out using an AUTOLAB PGSTAT 302N (Eco-Chemie B.V., Utrecht, The Netherlands) potentiostat-galvanostat with IME663 interface and NOVA 1.8 software. A standard three-electrode electrochemical assembly was used for all electrochemical experiments with BDDE as the working electrode, platinum wire as the counter electrode and $\mathrm{Ag} / \mathrm{AgCl}$ $(3 \mathrm{M} \mathrm{KCl})$ as the reference electrode. All pH measurements were made on a Mettler Toledo $\mathrm{pH}$ meter fitted with a glass electrode and a saturated calomel electrode as the reference which was pre-standardized with buffers of known $\mathrm{pH}$. All measurements were carried out at room temperature.

\subsection{Reagents and chemicals}

Phosphoric acid ( $\geq 98 \%$ ), boric acid $(\geq$ $99 \%)$, acetic acid (98\% purity) and $\mathrm{NaOH}(\geq$ 
97\%) were procured from Sigma (Mumbai, India) for the preparation of buffer solution. Pure doxofylline standard (98.9\% purity) was obtained as a gift from Shine Pharmaceuticals Pvt. Ltd. (Chennai, India). Tablets containing doxofylline (Doxoril-400 ${ }^{\circledR}$ ), labeled $400 \mathrm{mg}$, manufactured by Macleod Pharmaceuticals (Mumbai, India) were purchased from a commercial source. Ultra-pure water (Milli-Q water with resistivity of $18 \mathrm{M} \Omega \cdot \mathrm{cm}$ ) was obtained using an ELGA purification system (U.K.). All other chemicals used were of analytical grade and used without further purification.

\subsection{Preparation of standard and test solutions}

A standard solution of doxofylline (1 mg/ $\mathrm{ml})$ was prepared by dissolving the pure compound in water and was further diluted with BR buffer for drug analysis. For pharmaceutical formulation analysis, ten tablets of doxofylline (Doxoril-400®) were crushed into a fine powder and a test stock solution $(1 \mathrm{mg} / \mathrm{ml})$ was prepared using a sufficient amount of the crushed tablets, equivalent to $25 \mathrm{mg}$ of doxofylline in $25 \mathrm{ml}$ of water. Next, the solution was centrifuged at $3200 \mathrm{rpm}$ for $2 \mathrm{~min}$. The clear supernatant liquid of the test solution was withdrawn and diluted in B-R buffer to obtain a final concentration in the working range. Standard and test solutions were stored in the refrigerator at $4-8{ }^{\circ} \mathrm{C}$.

\subsection{Working voltammetric procedure}

The BDDE was polished using $0.3 \mu \mathrm{m}$ alumina on a Buehler microcloth, while the GCE was polished with fine emery paper followed by the use of $0.5 \mu \mathrm{m}$ alumina on the cloth. The electrodes were sonicated for $1 \mathrm{~min}$ and purging of nitrogen gas was done prior to every potential scan for $10 \mathrm{~min}$. About $10 \mathrm{ml}$ of the electrolyte solution containing the appropriate amount of standard doxofylline or the sample were added to the electrolytic cell. Then, the electrodes were immersed and the SWV and $\mathrm{CV}$ were recorded with the potential between 0.3 to $1.7 \mathrm{~V}$ and 0.5 to $1.7 \mathrm{~V}$, respectively.

\section{RESULTS AND DISCUSSION}

\subsection{Comparison of the electrochemical re- sponse of doxofylline on the BDDE and GCE}

The doxofylline solution system was investigated using the GCE at a fixed concentration to compare the electrocatalytic response of doxofylline with that of the BDDE. The SWV (Figure 1) and CV (Figure 2) were performed at the same concentration and the current values obtained revealed the higher sensitivity of the BDDE with an almost three-fold increase in current values towards doxofylline compared to the GCE. The BDDE was found to shift the peak potential of doxofylline on the lower side with reference to the peak potential obtained from the GCE.

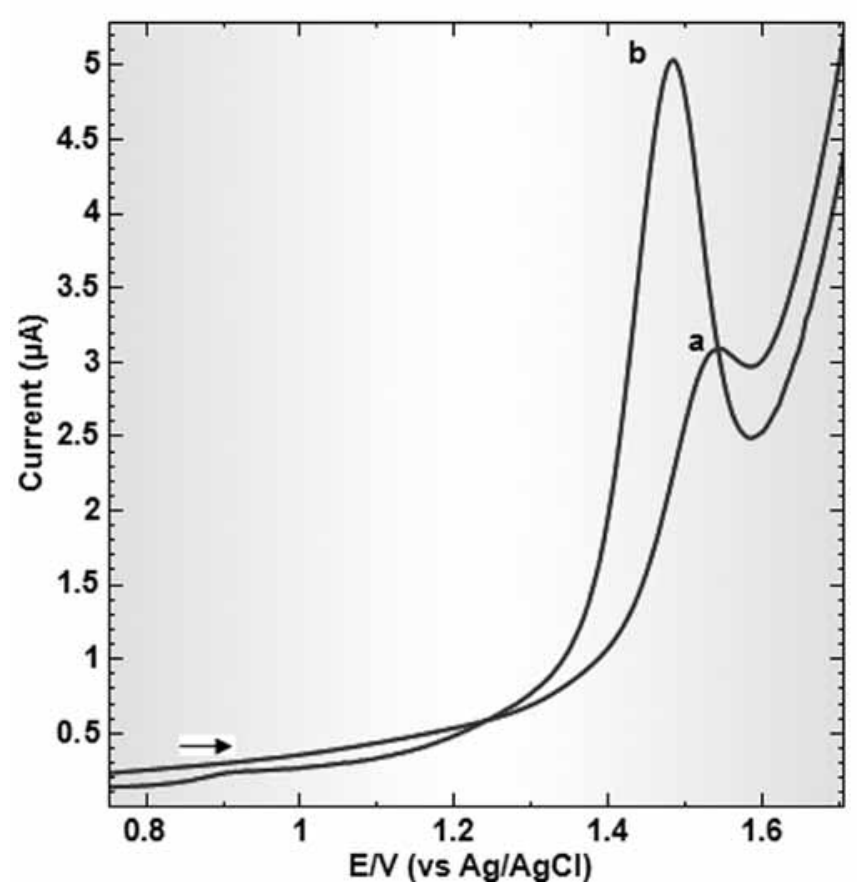

Fig. 1. SWV (amplitude: $20 \mathrm{mV}$, frequency: $25 \mathrm{~Hz}$, step potential: $5 \mathrm{mV}$, scan rate: $125 \mathrm{mV} / \mathrm{s}$ ) comparing the peak potential and current values of doxofylline obtained at a) GCE and b) BDDE prepared in BR buffer at a concentration of $25 \mu \mathrm{g} / \mathrm{ml}$ and $\mathrm{pH} 3.8$ 


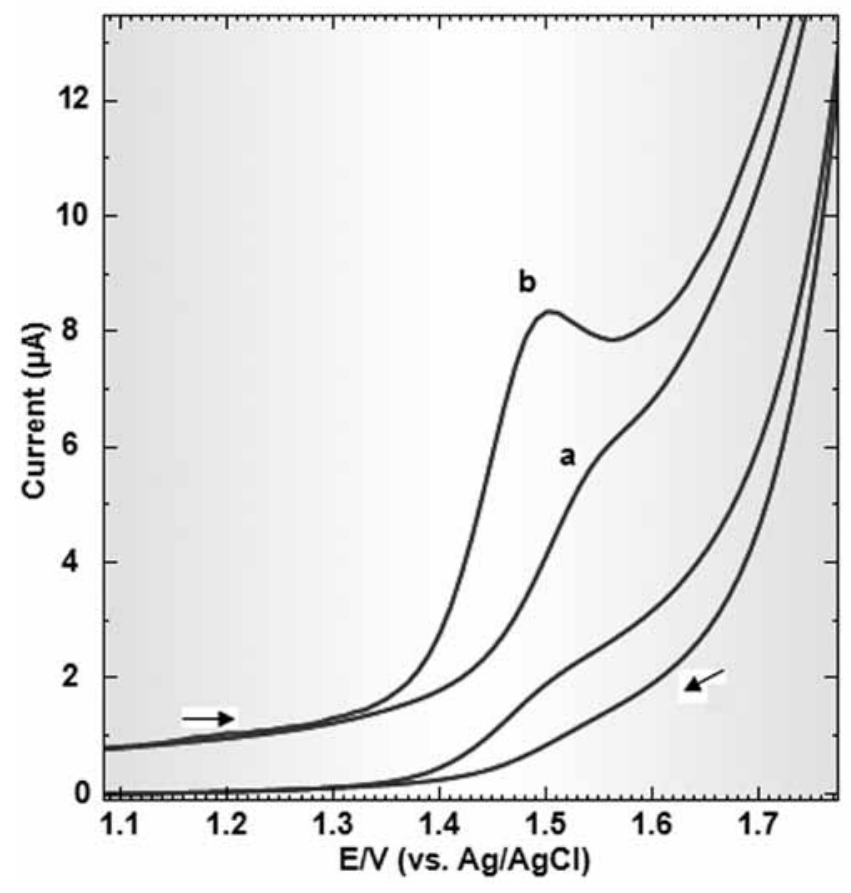

Fig. 2. CV comparing the peak potential and current values of doxofylline obtained at a) the GCE and b) the BDDE prepared in BR buffer at a concentration of $40 \mu \mathrm{g} / \mathrm{ml}$, a scan rate of $110 \mathrm{mV} / \mathrm{s}$ and $\mathrm{pH} 3.8$
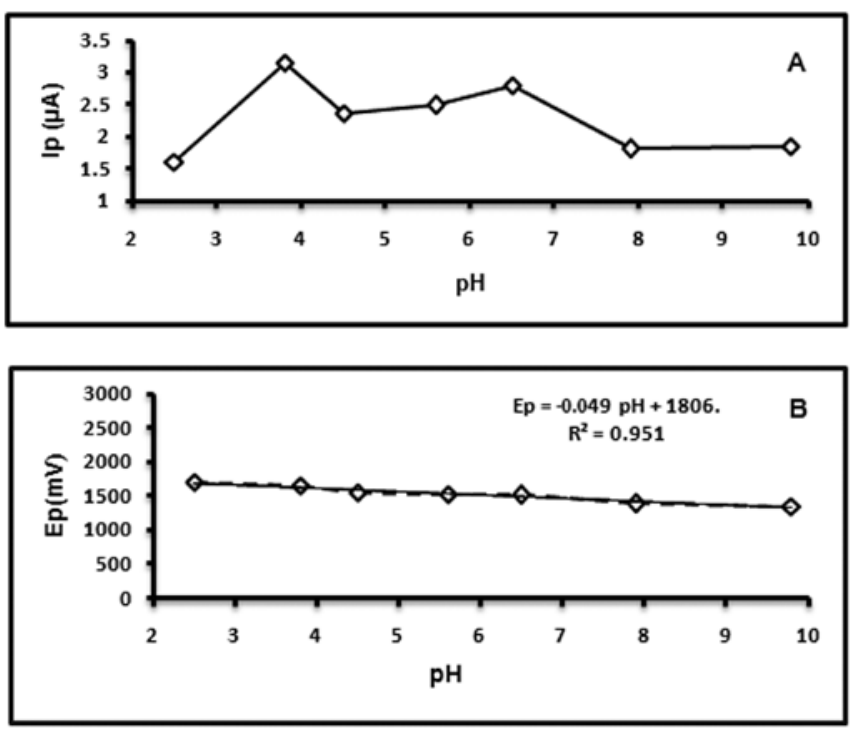

Fig. 3. Effect of $\mathrm{pH}$ on the anodic peak current (A) and potential shift (B) of doxofylline at a concentration of $40 \mu \mathrm{g} / \mathrm{ml}$ prepared in BR buffer, $\mathrm{pH} 3.8$

\subsection{Effect of $p H$}

In order to achieve the optimum buffer and optimum $\mathrm{pH}$ for the oxidation of doxofylline at the BDDE, the electrochemical behavior of the analyte was investigated in various buffers like phosphate, BR and acetate buffer. A well-defined oxidation peak was observed in BR buffer. Voltammetric behavior of doxofylline was finally studied in BR buffer at different $\mathrm{pH}$, ranging from 2.5 to 9.8 , with the maximum peak current observed at $3.8 \mathrm{pH}$ (Figure 3A). Similarly, Figure 3B shows that with an increase in the $\mathrm{pH}$ value, the peak potential decreased. The role of number of protons involved in the oxidation process was clear from the $E_{\mathrm{p}}$ vs. $\mathrm{pH}$ plot where $E_{\mathrm{p}}(\mathrm{mV})=1806-0.049$ $\mathrm{pH}$ and $R^{2}=0.951$. A slope of 0.049 per $\mathrm{pH}$ unit suggests that the number of electrons transferred is similar to that of hydrogen ions taking part in the electrode reaction.

\subsection{Effect of surfactants}

A voltammetric study of doxofylline was also performed with different solvents and surfactants. The experimental results (Figure 4A) show that the oxidation peak current of doxofylline was found to increase to a greater extent at the BDDE surface in the presence of SDS, indicating increased electron transfer in doxofylline. The peak current was attributed to the interaction of SDS with doxofylline and the BDDE. Surfactants can be adsorbed on the hydrophobic surface to form a surfactant film, which influences the rate of electron transfer. Alternatively, in the presence of SDS, the electrode may form a hydrophilic film with a negative charge. This layer may increase the concentration of doxofylline on the electrode surface. With an increase in peak current value, the peak potential also shifted to a lower potential in the case of SDS (Figure 4B). 


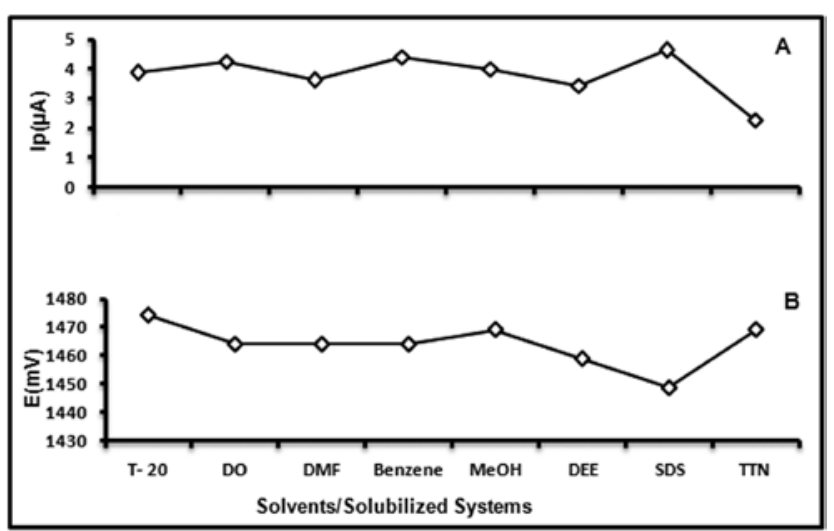

Fig. 4. Effect of surfactants and solvents on the square-wave peak current and potential of $40 \mu \mathrm{g} / \mathrm{ml}$ doxofylline prepared in BR buffer, $\mathrm{pH} 3.8$, with SDS showing lower potential and higher current values, as seen by the (A) anodic peak current and (B) potential shift in different solubilized systems

\subsection{Effect of scan rate}

To study the effect of the scan rate on the oxidation peak of doxofylline at the BDDE, voltammograms were recorded for different scan rates from $10-180 \mathrm{mV} / \mathrm{s}$ at a fixed concentration $(40 \mu \mathrm{g} / \mathrm{ml})$ of doxofylline. The anodic peak currents increased with an increase in the square root of the scan rate. A graph of anodic peak currents $\left(I_{\mathrm{p}}\right)$ vs. the square root of the scan rate (v) was plotted (Figure 5). The graph shows a linear relationship between the anodic peak current and the scan rate, which can be expressed by the following equation:

$$
I_{\mathrm{p}}(\mu \mathrm{A})=0.373(v)^{1 / 2}-0.136, R^{2}=0.999
$$

A linear plot of current $\left(I_{\mathrm{p}}\right)$ vs. the square root of the scan rate $(v)^{1 / 2}$ showed that the process was diffusion controlled [23]. The relationship between $E_{\mathrm{p}}$ and $\ln (v)$ of an irreversible process obeys the following equation [24]:

$$
\begin{gathered}
E_{p}=E^{0^{\prime}}+\frac{R T}{(1-\alpha) n F}\{0.780+ \\
\left.+\ln \left(\frac{D_{R}^{1 / 2}}{k^{\circ}}\right)+\ln \left[\frac{(1-\alpha) n F v}{R T}\right]^{1 / 2}\right\}
\end{gathered}
$$

$E^{o}$ is the formal redox potential; $R$ and $F$ values are $8.314 \mathrm{~J} / \mathrm{K} \cdot \mathrm{mol}$ and $96480 \mathrm{C} / \mathrm{mol} \mathrm{re}$ spectively, $k^{0}$ is the standard heterogeneous rate constant and $D$ is the diffusion coefficient. Based on the slope of the fitted line; $E_{\mathrm{p}}(\mathrm{V})=1.405+$ $0.016 \ln (v), R^{2}=0.988$ (Figure 6) $R T / 2(1-\alpha) n F$ $=0.016$, the value of $n(1-\alpha)$ at the experimental temperature of $298 \mathrm{~K}$ was calculated to be 0.8024 , with the electron transfer coefficient $(\alpha)$ found to be 0.58 from following equation [25]:

$$
\alpha=\frac{47.7}{E_{p}-E_{p / 2}}
$$

where $E_{\mathrm{p}}$ is the peak potential and $E_{\mathrm{p} / 2}$ is the potential where the current is at half the peak value. Here, the value of $n$ was found to be 1.90 , indicating the involvement of two electron transfers in the reaction process.

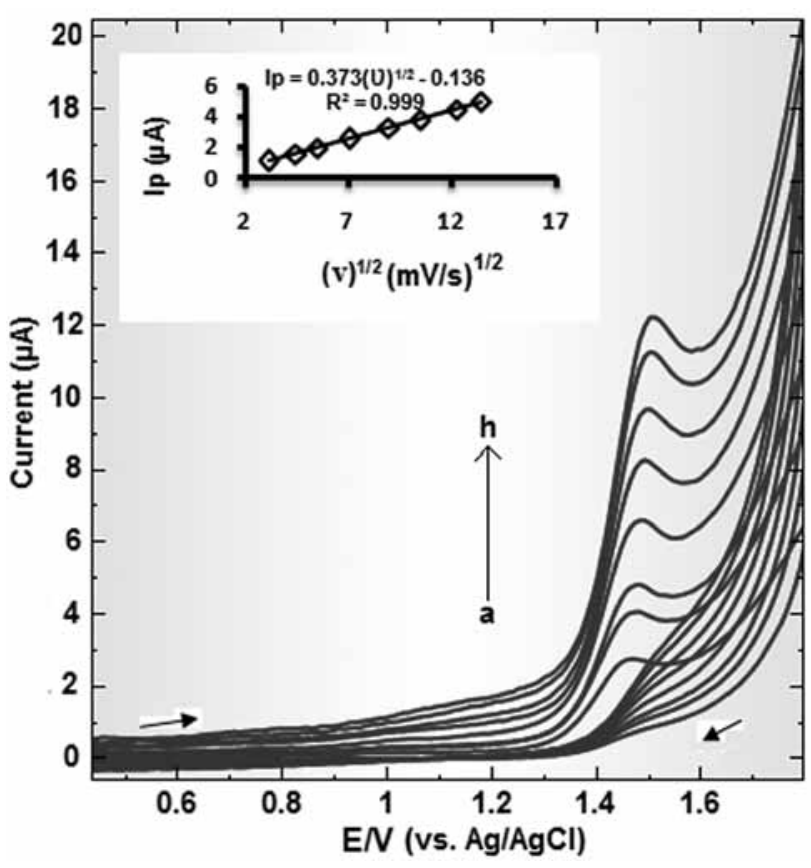

Fig. 5. CV of doxofylline $(40 \mu \mathrm{g} / \mathrm{ml})$ at $10-180 \mathrm{mV} / \mathrm{s}$ sweep rates, i.e. a) 10 , b) 20 , c) 30 , d) 50 , e) 80 , f) 110 , g) 150 and h) $180 \mathrm{mV} / \mathrm{s}$. The inset picture represents the calibration curve of anodic peak current $I_{\mathrm{p}}(\mu \mathrm{A})$ at different (sweep rates) (1/2 $^{1 / 2} \mathrm{BR}$ buffer at $\mathrm{pH} 3.8$ 


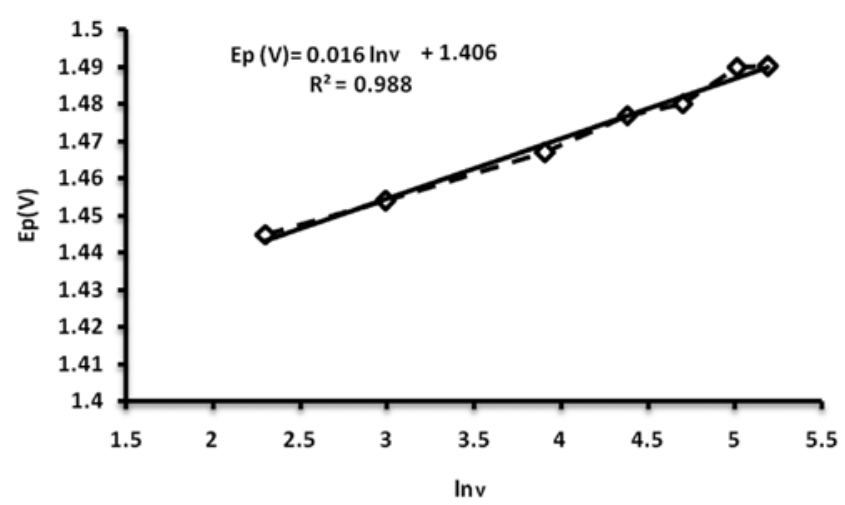

Fig. 6. Effect of scan rate shown as the linear curve of $E_{\mathrm{p}}$ vs. the logarithm of scan rates for the prediction of the oxidation mechanism

\subsection{Effect of concentration}

SWV obtained with increasing amounts of doxofylline showed that the peak current increased linearly with increasing concentration (Figure 7). A linear calibration curve was obtained for doxofylline over the range of 5-40 $\mu \mathrm{g} / \mathrm{ml}$, which can be expressed by the following equation:

$$
I_{\mathrm{p}}(\mu \mathrm{A})=0.092(\mu \mathrm{g} / \mathrm{ml})+0.719, \quad R^{2}=0.989
$$

The LOD and LOQ (Table 1) estimated as $3 \mathrm{~S} / \mathrm{m}$ and $10 \mathrm{~S} / \mathrm{m}$, respectively, were 3.48 and $10.56 \mu \mathrm{g} / \mathrm{ml}$, respectively, where $S$ is the standard deviation and $m$ is the slope of the calibration curve.

Table 1

\section{SWV method validation parameters for standard linearity}

\begin{tabular}{lr}
\hline \hline Linearity parameters & Results \\
\hline Slope & 0.0925 \\
Correlation coefficient & 0.9896 \\
Standard deviation & 0.0976 \\
Limit of detection & $3.48 \mu \mathrm{g} / \mathrm{ml}$ \\
Limit of quantification & $10.56 \mu \mathrm{g} / \mathrm{ml}$ \\
\hline \hline
\end{tabular}

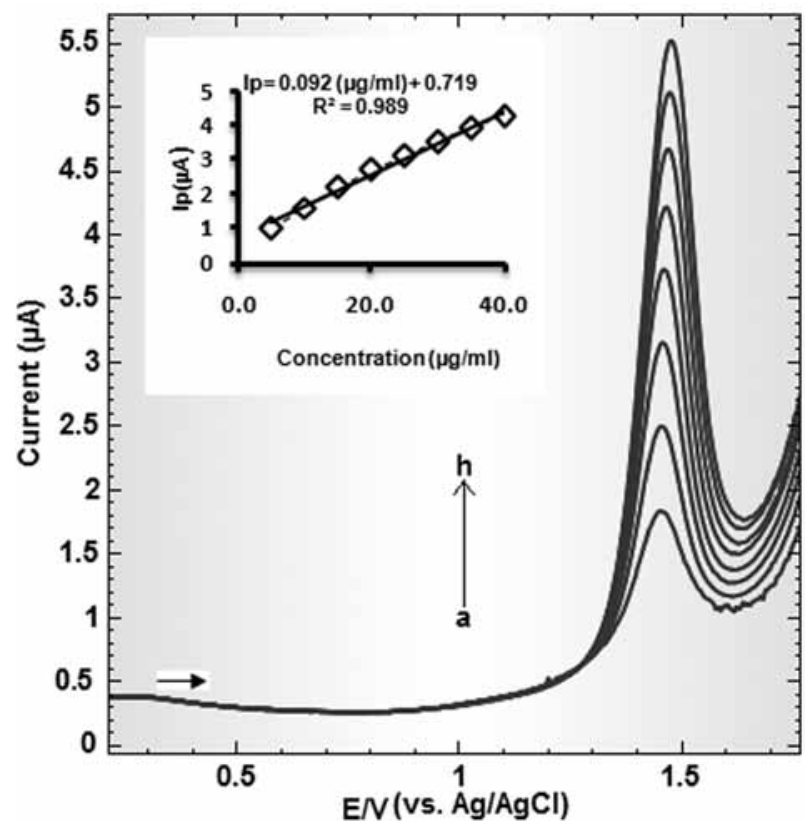

Fig. 7. Overlapping SWV (amplitude: $20 \mathrm{mV}$, frequency: $25 \mathrm{~Hz}$, step potential: $5 \mathrm{mV}$, scan rate: $125 \mathrm{mV} / \mathrm{s}$ ) of doxofylline at different concentrations,

5-40 $\mu \mathrm{g} / \mathrm{ml}$ : a) 5 , b) 10 , c) 15 , d) 20 , e) 25 , f) 30 , g) 35 and h) $40 \mu \mathrm{g} / \mathrm{ml}$ in BR buffer, $\mathrm{pH}$ 3.8. Inset picture represents the linearity curve at different concentrations.

\subsection{Voltammetric behavior of doxofylline}

Voltammetry techniques can provide general information about the electroactivity and possible surface activity of various compounds, as seen in case of doxofylline. The two hydroxyl groups are assumed to be added after the oxidation of the drug with $2 \mathrm{e}^{-}$and $2 \mathrm{H}^{+}$transfer, which is shown in Scheme 1. The mechanism deduced from the above voltammetric results and illustrations was found to be in support with the literature, as explained by Hegde et al. and Amare et al. [26, 27]. It is clear, for doxofylline, that the oxidation process is not accompanied by a reduction wave, which indicates that the oxidation reaction is totally irreversible (see Figure 5). The linearity of the current response of doxofylline in the case of the BDDE was more prominent with an increase in the peak height compared to the GCE at a fixed concentration. 
<smiles>CN1C(=O)N(C)C2(O)N=CN(CC3OCCO3)C2(O)C1=O</smiles>

Scheme 1. Proposed mechanism for doxofylline oxidation

\subsection{Determination of doxofylline in the pharmaceutical formulation}

The BDDE was used for the determination of doxofylline in the pharmaceutical formulation. The reliability of the electrode was investigated by applying the SWV technique. The determination of doxofylline in the pharmaceutical formulation has been reported in terms of accuracy (Figure 8, Table 2). The assay results indicate that the proposed voltammetric method can be effectively applied for the determination of doxofylline in the pharmaceutical formulation. The concentration of the unknown drug can be determined using the standard addition method by the following equation [28]:

$$
C_{\mathrm{u}}=\frac{I_{\mathrm{p} 1} C_{\mathrm{s}} V_{\mathrm{s}}}{\left[I_{\mathrm{p} 2}\left(V_{\mathrm{u}}+V_{\mathrm{s}}\right]-I_{\mathrm{p} 1} V_{\mathrm{u}}\right.}
$$

After obtaining the voltammogram of the supporting electrolyte, a known volume $\left(V_{\mathrm{u}}\right)$ of an unknown concentration $\left(C_{\mathrm{u}}\right)$ of the investigated drug is added and the resulting voltammogram is recorded and the peak current $\left(I_{\mathrm{p} 1}\right)$ is measured. Next, a known volume $\left(V_{\mathrm{s}}\right)$ of a known concentration $\left(C_{\mathrm{s}}\right)$ of a standard pure drug is added and the peak current $\left(I_{\mathrm{p} 2}\right)$ is measured.

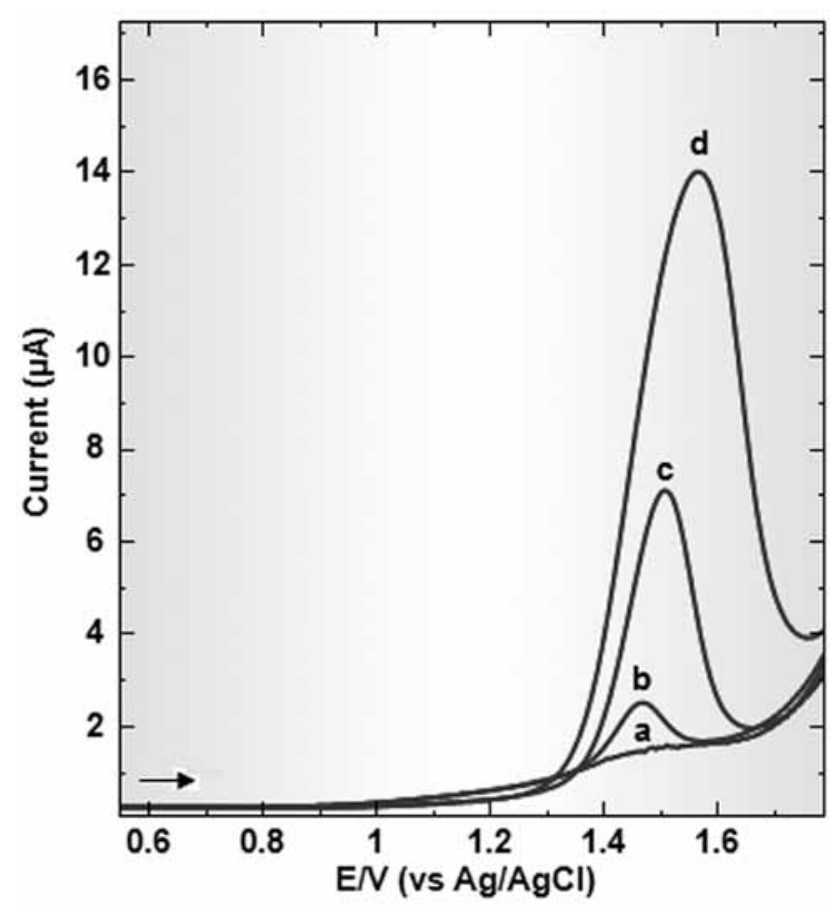

Fig. 8. Square-wave voltammetric determination by standard addition calibration of doxofylline (amplitude: $20 \mathrm{mV}$, frequency: $25 \mathrm{~Hz}$, step potential: $5 \mathrm{mV}$ and scan rate: $125 \mathrm{mV} / \mathrm{s}$ ); a) blank (BR buffer, pH 3.8), b) sample, c) addition $1(75 \mu \mathrm{g} / \mathrm{ml})$, d) addition $2(150 \mu \mathrm{g} / \mathrm{ml})$.

Table 2

Determination of doxofylline in the pharmaceutical formulation (Doxoril-400®) by the proposed voltammetric method

\begin{tabular}{cccc}
\hline \hline $\begin{array}{c}\text { Amount added } \\
(\mu \mathrm{g} / \mathrm{ml})\end{array}$ & $\begin{array}{c}\text { Amount found } \\
(\mu \mathrm{g} / \mathrm{ml})\end{array}$ & $\begin{array}{c}\text { Accuracy }^{a} \\
\%\end{array}$ & $\begin{array}{c}\mathrm{CV} \\
\%\end{array}$ \\
\hline 75 & 74.29 & 99.05 & 1.02 \\
150 & 148.67 & 99.11 & 0.86 \\
300 & 298.17 & 99.39 & 0.54 \\
\hline \hline
\end{tabular}

$\bar{a}$ (Amt. found / Amt. added $) \times 100]$ 


\section{CONCLUSION}

Conclusively, BDDE was found to be appropriate and effective for the selective determination of doxofylline in BR buffer at $\mathrm{pH}$ 3.8. The electrode reaction process dynamic parameters were investigated and the reaction mechanism was proposed and discussed in the work. BDDE showed up to a three-fold enhancement in the current response when compared with that of the GCE. The variation of scan rate study showed that the electrode process is diffusion-controlled. The calibration plot revealed linearity within the range of $5-40 \mu \mathrm{g} /$ $\mathrm{ml}$ with a correlation coefficient of 0.989 . The LOD and LOQ were $3.48 \mu \mathrm{g} / \mathrm{ml}$ and $10.56 \mu \mathrm{g} /$ $\mathrm{ml}$, respectively.

Acknowledgments. The authors acknowledge the Ministry of Human Resource Development project, Dayalbagh Educational Institute, Dayalbagh, Agra, India, for providing financial assistance under an NMEICT project.

\section{REFERENCES}

[1] X. Kang, J. Wang, H. Wu, J. Liu, I. A. Aksay, Y. Lin, A graphene based electrochemical sensor for sensitive detection of Paracetamol, Talanta, 81, 754-759 (2010).

[2] F. G. Marc, C. Paul, Efficacy and safety of doxofylline compared to theophylline in chronic reversible asthma - a double-blind randomized placebo-controlled multicentre clinical trial, Med. Sci. Monit., 8(4), CR297-304 (2002).

[3] F. Villani, P. De Maria, E. Ronchi, M. Galimberti, Oral doxophylline in patients with chronic obstructive pulmonary disease, Int. J. Clin. Pharmacol. Ther., 35, 107 (1997).

[4] F. L. Dini, L. D. Frank, C. Roberto, Doxofylline: A new generation xanthine bronchodilator devoid of major cardiovascular adverse effects, Curr. Med. Res. Opinion., 16, 258-268 (2000).

[5] H. R Joshi, A. H Patel, A. D. Captain, Spectrophotometric and reversed-phased high performance liquid chromatographic method for the determination of doxofylline in pharmaceutical formulations, J. Young Pharm., 2, 289-296 (2010).
[6] F. Tagliaro, R. Dorizzi, A. Fregario, M. Marigo, Non-extraction HPLC method for simultaneous measurement of dyphylline and doxofylline in serum, Clin. Chem., 36, 113-115 (1990).

[7] M. B.Lagana, A. Marino, M. Mancini, Solid phase extraction and high performance liquid chromatographic determination of doxophylline in Plasma, Biomed. Chromatogr., 4, 205-207 (1990).

[8] M. Ashu, P. Shikha, Development and validation of rapid HPLC method for determination of doxofylline in bulk drug and pharmaceutical dosage forms, J. Anal. Chem., 65, 293-297 (2010).

[9] B. Umadevi, T. Vetrichelvan, Development and validation of UV spectrophotometric determination of doxofylline and ambroxol hydrochloride in bulk and combined tablet formulation, Int J Curr Pharm Res, 3, 89-92 (2011).

[10] G. P. Narendra, L. Sathiyanarayanan, V. M. Mahadeo, R. D. Sunil, A validated, stability indicating HPTLC method for analysis of doxofylline, J.Planar Chromatogr. Mod. TLC., 22, 345-348 (2009).

[11] R. Gannu, S. Bandari, S. G. Sudke, Y. M. Rao, B. P. Shankar, Development and validation of a stability-indicating RP-HPLC method for analysis of doxofylline in human serum. Application of the method to a pharmacokinetic study, Acta. Chromat., 19, 149-160 (2007).

[12] N. Sreenivas, M. L.Narasu, B. P. Shankar, R. Mullangi, Development and validation of a sensitive LC-MS/MS method with electrospray ionization for quantitation of doxofylline in human serum: application to a clinical pharmacokinetic study, $B i$ omed. Chromatgr., 22, 654-661 (2008).

[13] R. Jain, V. K. Gupta, N. Jadon, K. Radhapyari, Voltammetric determination of cefixime in pharmaceuticals and biological fluids, Anal. Biochem., 407, 79-88 (2010).

[14] R. Jain, V. K. Gupta, N. Jadon, K. Radhapyari, Adsorptive stripping voltammetric determination of pyridostigmine bromide in bulk, pharmaceutical formulations and biological fluid, J. Electroanal. Chem., 648, 20-27 (2010).

[15] R. Jain, R. K. Yadav, Voltmmetric assay of antianginal drug nicorandil in different solvents, Drug Test. Analysis, 3, 171-175 (2011).

[16] R. Jain, J. A. Rather, Voltammetric determination of antibacterial drug gemifloxacin in solubilized systems at multi-walled carbon nanotubes modified glassy carbon electrodes, Colloids and Surfaces, B: Biointerfaces, 83, 340-346 (2011). 
[17] R. Jain, J. A. Rather; Stripping voltammetry of tinidazole in solubilized system and biological fluids, Colloids and Surfaces, A: Physicochem. Eng. Aspects, 378, 27-33 (2011).

[18] R. Jain, R. K. Yadav, A. Dwivedi, Square-wave adsorptive stripping voltammetric behavior of entacapone at HMDE and its determination in the presence of surfactants, Colloids and Surfaces, A: Physicochem. Eng. Aspects, 359, 25-30 (2010).

[19] M. Panizza, G. Cerisola, Application of diamond electrodes to electrochemical processes, Electrochim. Acta, 51, 191 (2005).

[20] M. A. Q. Alfaro, S. Ferro, C. A. Martínez-Huitle, Y. M. Vong, Boron doped diamond electrode for waste water treatment, J. Braz. Chem. Soc., 17, 227 (2006).

[21] W. Haenni, P. Rychen, M. Fryda, C. Comninellis, in: Thin-Film Diamond, Part B, Ch. Nebel (editor), Academic Press, Semiconductors and Semimetals series, Elsevier, 2004, p. 149.

[22] Kraft, Doped Diamond: A Compact review on new, versatile electrode material, Int. J. Electrochem. Sci., 2, 355-385 (2007).
[23] T. Laixing, F. Wang, Y. Y. Mao, L. P.Wang, B. X. Ye, Electrochemical behaviour of apigenin at a glassy carbon electrode and its analytical application. J. Chin. Chem. Soc., 56, 303 (2009).

[24] R. S. Nicholson, I. Shain, Theory of Stationary electrode polarography: Single scan and cyclic methods applied to reversible, irreversible and kinetic systems, Anal. Chem., 36, 706 (1964).

[25] A. J. Bard, L. R. Faulkner, Electrochemical methods fundamentals and applications, Wiley, New York, 1980.

[26] R. N. Hegde, R. R. Hosamani, S. T. Nandibewoor, Electrochemical oxidation and determination of theophylline at a carbon paste electrode using cetyltrimethyl ammonium bromide as enhancing agent, Anal. Lett., 42, 2665-2682, (2009).

[27] M. Amare, S. Admassie, Differential pulse voltammetric determination of theophylline at poly (4-amino-3-hydroxynaphthalene sulfonic acid) modified glassy carbon electrode, Bull. Chem. Soc. Ethiop., 26(1), 73-84, (2012).

[28] G. W. Ewing, Instrumental methods of chemical analysis, 5th ed.; Lippincott - Raven: Philadelphia, 1995 , p. 465. 
